\title{
Mapping of Flood Prone Areas in Surulere, Lagos, Nigeria: A GIS Approach
}

\author{
Chidinma Blessing Okoye ${ }^{1}$, Vincent Nduka Ojeh ${ }^{2}$ \\ ${ }^{1}$ Department of Geography, University of Lagos, Akoka, Nigeria \\ ${ }^{2}$ Wascal, Department of Meteorology, Federal University of Technology, Akure, Nigeria \\ Email: drojehvn@hotmail.com
}

Received 16 February 2015; accepted 11 April 2015; published 15 April 2015

Copyright (C) 2015 by authors and Scientific Research Publishing Inc.

This work is licensed under the Creative Commons Attribution International License (CC BY). http://creativecommons.org/licenses/by/4.0/

(c) (i) Open Access

\begin{abstract}
Increase in the frequency of flooding incidents all over the world and indeed in Nigeria is a major cause for concern. The purpose of this research work is to identify the factors that lead to flooding; and using Geographic Information Systems, map the flood prone areas in Surulere. The causal factors of flooding in Surulere, such as high rainfall intensity and duration, land use patterns, human actions, urbanization, soil impermeability to mention but a few were identified. The pattern of rainfall in Surulere was analysed using 20 years rainfall data from The Nigerian Meteorological Agency. The land use/land cover map as well as the DEM of Surulere was generated in the ArcGis environment with ikonos imagery and 1:50,000 toposheet of Lagos S.E which covers Surulere. The Flood prone areas in Surulere were then mapped. Results show that majority of the land area of Surulere is prone to flooding. Flood mitigation such as early warning systems and flood forecasting, proper urban development, awareness and research should be implemented by the Lagos State Government.
\end{abstract}

\section{Keywords}

\section{GIS, Flooding, Surulere, DEM}

\section{Introduction}

Ojeh and Ugboma [1] asserted that flooding is arguably the weather-related hazard that is most widespread around the globe. Flooding is an event which occurs when there's an overflow of water that submerges land. Flood is one of the natural environmental hazards ravaging the landscape of mankind over the years and whenever flood occur, they result in the loss of properties, lives, destruction of farmlands etc. in most towns in the world [2]. According to [3] flood is an extreme weather event naturally caused by rising global temperature which results in heavy downpour, thermal expansion of the ocean and glacier melt, which in turn results in rise 
in sea level, thereby causing salt water to inundate coastal lands. Floods or flood waters are temporary inundation of normally dry land areas from the overflow of inland or tidal waters, or from the unusual and rapid accumulation or runoff of surface waters from any source onto lands that are used or usable by man and not normally covered by water [4].

Flooding incidences are becoming a more frequent occurrence in Nigeria. Between 2011 and 2012, there were a number of reported cases of flooding in several parts of the country. The major floods that overtook most parts of Kogi, Delta and Bayelsa states and Onitsha in 2012 is an example (See Figure 1 below). Areas around the River Niger were totally submerged by floods and over 600,000 residents were rendered homeless, farmlands lost and many killed [5]. Like [6] rightly said "In the year 2012, Nigeria witnessed the highest flood disaster in 100 years, where over ten states of the Federation came greatly under water". According to experts, the floods were caused by excess rainfall which resulted in the over flooding of Rivers Niger and Benue and their tributaries, from Taraba to Adamawa all the way to the southern states of Nigeria [5]. This incident was predicted by The Nigerian Meteorological Agency.

In Lagos, it has become a normal phenomenon for floods to accompany heavy and or prolonged rains. The July 10th flood of year 2011 is perhaps an incident that Lagosians would not forget in a hurry, as there were many devastating effects of the flood. This year also, there have been cases of severe flooding in Lagos after a heavy downpour of rain. On June 28th 2012, Lagos residents were enveloped by floods resulting from a heavy downpour of rain which started the night before and lasted for several hours. A number of houses and roads were submerged by the floods and some people lost their lives. Sections of Lagos-Abeokuta expressway were cut off on both sides by the flood and a portion of the Murtala Mohammed International airport road by Mobil Filing station was submerged. The worst hit areas were Okokomaiko, GRA Ikeja, Ipaja-Ayobo, Shogunle, Apapa, Shomolu, Magodo, Ejigbo and Surulere areas of Lagos state (see Figure 1 and Figure 2). Figure 2 shows a flooded street in Aguda, Surulere after a rainfall event.

Flooding is a big problem in Surulere, even during the mild rainfalls streets are flooded and many times water rises to house levels. Intensity of rainfall in short period, in rainy season, leads to extremely high runoffs and floods. Surulere is a lowland which makes the situation even worse because the lowland nature hinders water discharge to the sea. Also, due to poor soil infiltration only a small proportion of rainwater seeps into the ground [7]. Because of poor infrastructure planning, buildings often block natural watercourses and canals are too narrow to convey rainwater away from the area. Roads are often unpaved and the hard rain makes them muddy and bumpy. Inhabitants of the LGA wish to have expanded canals, paved roads and better drainage to prevent flooding of homes and other problems during the rains.

The incessant flooding incidents in Lagos and hence Surulere have become a major cause of concern especially because of its disastrous aftermath. At the onset of the rainy season in 2013, The Lagos State government indicated that Surulere LGA is one of the parts of Lagos that are in danger of being flooded. This frequent incident has been linked to changes in the precipitation pattern in area with more rains with higher frequency and

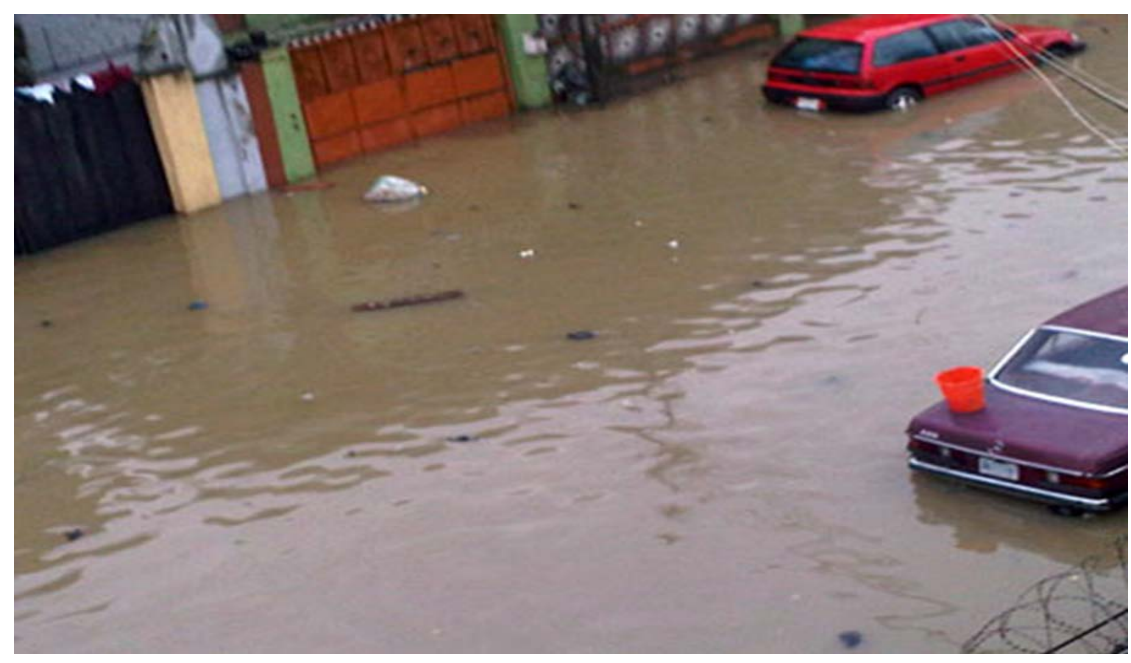

Figure 1. Aerial photograph of flood submerged area in Kogi [8]. 


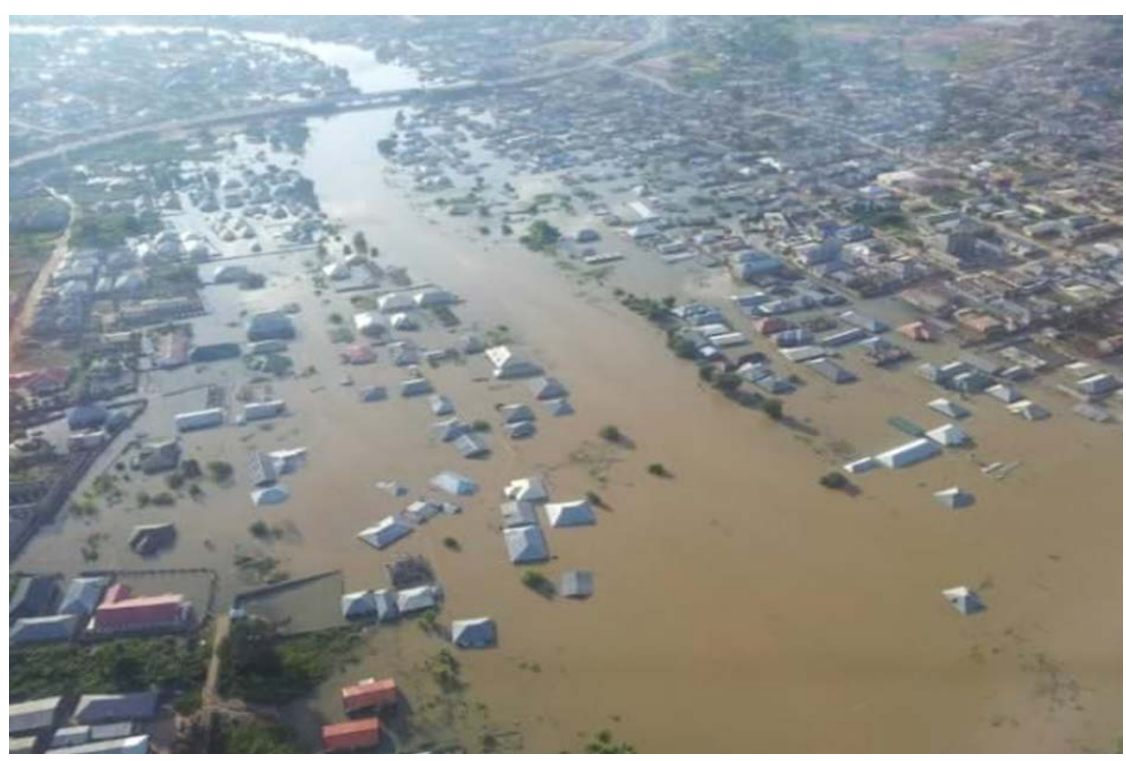

Figure 2. A flooded Ijewere street in Aguda, Surulere [9].

intensity. Also, the relief of Surulere, (which is relatively lowland) contributes as it prevents water discharge to the sea. Due to the poor infrastructural planning, buildings often block natural water drainage systems and roads constructed without drainage prevents rainwater from flowing out. Thus, it has become necessary to identify the immediate and indirect causes of flooding in Surulere, and map out the parts of the LGA that are more susceptible to flooding using GIS, so as to proffer solutions to the flooding situation in Surulere.

\section{Conceptual Issues and Related Literature}

This study hinges on the GIS concept. Geographic refers to anything that relates to space or the arrangement (location and distribution) of objects in space. It implies an interest in the locational identity of any object on, under or above the earth's surface. Information are facts resulting from the processing or refining of raw data. Such facts are usually meaningful, hence of value to some users and could be used for decision making. Geographic information is any information or data that has geographic identity, i.e. its specific location or in relation to the surface of the earth is known. A system is an organised assemblage or collection of interrelated components (subsystems), which harmoniously interact with one another towards accomplishing some desired results or pre-defined goals.

A GIS is thus an orderly assemblage of computer-based hardware, software, geographically referenced data, procedures, and human ware (personnel) configured to handle all forms of spatial data to satisfy the geographic information needs of a user [10] According to [11], the field of geographic information systems (GIS) is concerned with the description, explanation, and prediction of patterns and processes at geographic scales. GIS is a science, a technology, a discipline, and an applied problem solving methodology. Simply put, a GIS is an application used to deal with or process spatial information on the computer [12].

Like every other system, A GIS consists of some distinct but fundamentally related components parts. They include hardware, software, data, procedure and personnel or human ware. The hardware refers to the physical computer system and associated accessories necessary for running a GIS software as well as the capture, storage, manipulation and output of spatial data. A typical GIS software often contains tools in form of algorithms (programs, rules or commands) for performing certain tasks as data input, storage, retrieval, analysis, query, output and updating. GIS data refers to facts or information about some geographic feature and includes both geographic and attribute data. There are several procedures involved in a GIS and they include data acquisition, input, storage, sorting, indexing, retrieval, analysis, output and updating, along with the process of decision making. GIS personnel or human ware refer to a group of experts who one way or use or promote the use of GIS and allied facilities such as manufacturers of GIS hardware and software, GIS data providers, managers, users of GIS technology, consultants and so on. 
There is a large range of application areas of GIS. They include topographic base mapping, socio-economic and environmental modelling, global (and interplanetary) modelling, and education. Applications generally set out to fulfill the five Ms of GIS i.e. mapping, measurement, monitoring, modelling and management [11].

Reference [13] stated that "Apart from traffic congestion, flood is the most common serious physical urban problem in most Nigerian cities". According to them, flooding usually results from high river levels, concentration of overland flow following heavy rainfall, limited capacity of drainage systems and blockage of waterways and drainage channels. Reference [1] observed that flooding in Abraka, the host town of Delta State University, has resulted to the inaccessibility of some roads, destruction of properties, lateness to school, forced migration/ relocation and traffic congestion in the area and therefore has negative effect on socioeconomic activities leading to decrease in the productivity of the people.

In their study on natural hazard and crop yield, [2] stated that there was a high level of inundation in farmlands in Oleh soon after every rain event. A mean value of 0.608 kilometres of flooded portion was recorded at Odah in 2011, 0.441 kilometers at Iwhreotah in 2011, 0.547 kilometres at Erorin in 2011 and 0.485 kilometres at Odah in 2012, 0.425 kilometres at Iwhreotah in 2012 and 0.598 kilometres of flooded portion in 2012 at Erorin quarters were generally observed in the farm lands. The study revealed that all the crops cultivated in the area (cassava, melon, yam, maize, plantain) were affected by flooding above 50 percent of total yield of each crop cultivated in the area except yam (46.9\%).

[14] wrote on the Environmental Impact of flooding on Kosofe LGA of Lagos State. They stated that the causes of flood tend to vary from one locality to another depending on the available protection and management process. Urbanization and or the concentration of settlements have continued to raise the flood damage, as settlements continue to encroach on the flood prone areas. They also indicated that over reliance on safety provided by flood control infrastructure such as levies, dykes, reservoirs, dam can also result in flood disaster. For example dyke though a flood protective structure can collapse, thereby resulting into immense water destruction. Human action also causes flooding; there is the tendency to encroach on flood plains which attract development due to their flatness, soil fertility and proximity to water. According to them, other causes of increasing flood risk include increase in the proportion of impervious area; deforestation and channel interference e.g. channel suffocation by solid waste.

[15] discussed the negative social impacts of flooding. According to the article, flooding of areas used for socio-economic activities produces a variety of negative impacts. The magnitude of adverse impacts depends on the vulnerability of the activities and population and the frequency, intensity and extent of flooding. Some of the negative impacts highlighted are: Loss of lives and property, loss of livelihood, decreasing purchasing and production power, mass migration, psychosocial effects, hindering of economic growth and development and political implications.

[16] stated as thus- "High rainfall and consequent floods are recurrent phenomenon in India causing loss of lives and damage to livelihood, property, infrastructure and public utilities. However, these events also provide opportunities of positive effects”. The positive impacts of floods highlighted include ground water recharge, enhanced water availability in dams/reservoirs, and deposition of fertile silt on flood plains. Surulere is yet to be given adequate research attention for future planning purposes, thus, this study is geared towards making contribution to existing body of literatures from the GIS mapping perspective to flooding in Surulere.

\section{Methodology}

\subsection{The Study Area}

Surulere is a local government Area of Lagos State. It is located on the Lagos mainland between $6^{\circ} 05^{\prime} \mathrm{N}$ and $6^{\circ} 30^{\prime} \mathrm{N}$ of the equator and $3^{\circ} 21^{\prime} \mathrm{E}$ and $3^{\circ} 35^{\prime} \mathrm{E}$ of the Greenwich meridian (Figure 3). Surulere is a residential and commercial area, with a land area of $27.05 \mathrm{sq}$. km. It is part of Metropolitan Lagos. The boundary of Surulere LGA is as follows: On the North, the road that separates Ransome Kuti School through Bishop Street to include Obele-Oniwala up to boundary with Itire at Mushin Local Government; South—-the roundabout to Costain to include the whole Abebe village and Eric Moore; East - the railway crossing at Yaba to exclude Railway compound through the swamp at Alaska estate and West-Nepa's high-tension cable on the other side of Jubril Martins through Masha to include both sides of Adelabu street, old census office to Babs Animashaun. Therefore, it can be said that Surulere is bounded on the north by Mushin and Shomolu LGAs, on the South by Ajeromi-Ifelodun and Apapa, on the West by Oshodi-Isolo and Amuwo-Odofin and on the East by Lagos Mainland. 


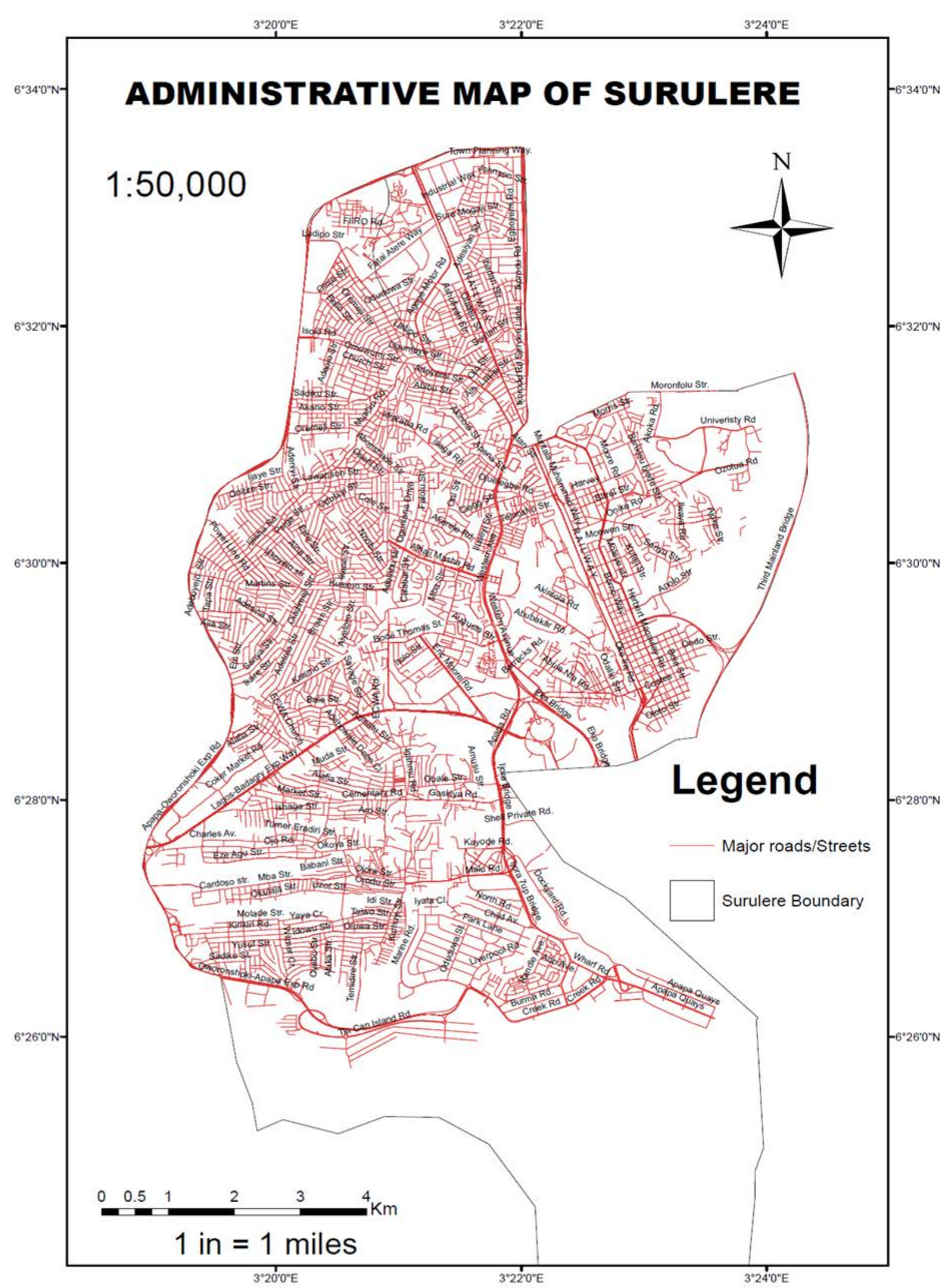

Figure 3. Administrative map of Surulere. 
However, for the purpose of this work, the immediate environs (surroundings) of Surulere was considered i.e. Oshodi, Mushin, and Lagos Island axis for a holistic view.

Surulere has a tropical wet and dry climate (Köppen climate classification Aw) that borders on a tropical monsoon climate (Köppen climate classification Am). It has a tropical savanna climate that is similar to that of the rest of southern Nigeria. There are two climatic seasons in a year-The rainy season, which lasts from April to October and the rainy season, which lasts from November to March. The heaviest rains fall from April to July and a weaker rainy season occurs in October and November. The peak months of the rainy season are the months of June and July. There is a brief relatively dry spell in August and September and a longer dry season from December to March. The mean monthly rainfall between May and July is about $300 \mathrm{~mm}$ while in August and September it is down to $75 \mathrm{~mm}$ and in January, it is as low as $35 \mathrm{~mm}$. Generally, however, the mean monthly rainfall through the year is about $120 \mathrm{~mm}$, while the total annual rainfall is almost $1500 \mathrm{~mm}$.

The main dry season is accompanied by winds from the Sahara Desert which between December and early February can be quite strong. The average temperature in January is $27^{\circ} \mathrm{C}$ and for July it is $25^{\circ} \mathrm{C}$. On average the hottest month is March with a mean temperature of $29^{\circ} \mathrm{C}$ while July is the coolest month but still there doesn’t exist much of the hot months. The dominant vegetation in Surulere is tropical swamp forest, comprising fresh waters and mangrove swamp forests.

Surulere is a generally low land covered by nearly uniform terrain made up of mainly sandy soil. The geology consists of quaternary alluvial deposits such as ferralitic red-yellow soil, red-brown, grey and sandy clays, silt, sand gravels and cowrie shells amongst other detrital materials. In slightly elevated upland areas where dry patches occur, the rock type is sedimentary basement complex of Precambrian origin with deposits of rare tainted lignites. The average elevation of Surulere is about $10 \mathrm{~m}$ above sea level. Although there are no major water bodies in Surulere LGA, the major water bodies in Lagos state are the Lagos and Lekki Lagoons, Yewa and Ogun rivers. Rivers flowing to the sea form swampy lagoons like Lagos Lagoon behind long coastal sand spits or sand bars. Some rivers, like Badagry Creek, flow parallel to the coast for some distance before exiting through the sand bars to the sea.

Surulere LGA, as of the 2006 census has an estimated population of 1,274,362 people, with 698,403 males and 575,959 females. With a land mass of 27.05 sq. $\mathrm{km}$, the population density is 47111.35 people per sq. $\mathrm{km}$. The population of Surulere is projected to increase to 1,639,572 by 2014 with a population density of 60,613 and 1,692,038 by 2015 with a population density of 62,552; using an annual growth rate of 3.2\% [17].

Surulere is a residential and commercial area, with majorly residential areas and a few commercial centres. The Ojuelegba area of Surulere is a major hub of commercial activities, with the former Tejuosho market situated along Ojuelegba road towards the railway axis. The Aguda and Iponri markets are also major markets in the LGA. Streets such as Adeniran Ogunsanya Street, Akerele Street, Ogunlana Drive are major streets where commercial activities also take place. The National and Lagos State Stadiums are both situated in Surulere and serve as sport recreational centres.

\subsection{Research Instrument/Data}

Primary data

1) 1:50,000 topographic map of Lagos S.E covering Surulere Local Government.

2) A map of Surulere, showing the boundary.

3) Ikonos satellite imagery with resolution of $1 \mathrm{~m}$ covering Surulere LGA (see Table 1 for Specifications of the Ikonos Imagery).

4) 20 years (1991-1998; 2000-2011) monthly rainfall data of Oshodi met station from NIMET. Data for 1999 was not available.

Secondary Data

1) Available data on past recorded flooding incidents in Lagos.

2) Field surveys.

Hardware and Software

1) Hp 630 notebook personal computer with 2 gigabyte RAM, 64-bit operating system and 283 gigabyte local disk memory

2) HP Office jet 5600 series printer 
Table 1. Specifications of the Ikonos Imagery.

\begin{tabular}{cl}
\hline Spectral Resolution & \multicolumn{1}{c}{ Im } \\
\hline & Band 1 (blue) 0.445 - 0.516 micrometers \\
Spectral Range & Band 2 (green) 0.506 - 0.595 micrometers \\
& Band 3 (red) 0.632 - 0.698 micrometers \\
& Band 4 (near infrared) 0.757 - 0.853 micrometers \\
Radiometric Resolution & 11 bits per pixel \\
Temporal Resolution & 3 days \\
Datum & WGS84 \\
Sun Angle & $>15^{\circ}$ \\
\hline
\end{tabular}

3) Arc.GIS 10.0 software

4) Envi 4.7 software

\subsection{Identifying the Factors That Contribute to Flooding in Surulere}

In identifying the factors that contribute to flooding in Surulere, field surveys were carried out by going to a few selected parts of Surulere (Ground truthing).

The rainfall data collected for (Ikeja met station) was analysed to see the rainfall trend in the study area over the years. This was backed up by literature research and the results of the analysis carried out.

\subsection{Extraction of the Surulere Map from the Lagos S.E Toposheet}

- The ArcGis 10.0 software was launched.

- The 1:50,000 toposheet of Lagos S.E, sheet 279 S.E. of the Nigerian topographic sheet series (Federal Surveys Nigeria, 1966), which was in raster format was then brought into the GIS environment by clicking the add data icon and importing the map from the folder it was saved. The toposheet is shown in Figure 4. The boundary map of Surulere was also imported into the GIS environment.

- The maps and the data frame were spatially referenced using the World Geographic Coordinate System (WGS) 1984 referencing system.

- The Lagos S.E toposheet and the Surulere Boundary map were then georeferenced by launching the georeferencing toolbox and using the add control points tool to pick out points on the 4 edges of the map and inputing the coordinates, which is then saved by clicking rectify on georeferencing dialogue box and clicking update georeferencing.

- The arc catalogue was launched and the editor toolbox was launched.

- A file geodatabase was created and the imported Surulere boundary map was digitized, by using the edit tool in the editor toolbox to pick out points round the boundary, which was then saved.

- The digitized boundary map was then overlayed on the Lagos S.E toposheet.

- The ArcToolbox was launched and the Surulere toposheet was extracted by clicking on spatial analyst tools under the ArcToolbox $\rightarrow$ extraction $\rightarrow$ extract by mask $\rightarrow$ input raster (the Lagos S.E toposheet) $\rightarrow$ input raster or feature mask data (boundary) $\rightarrow$ output raster $\rightarrow$ ok.

\subsection{Generation of a Relief Map of Surulere}

- Two (2) File Geodatabase layers were created from the ArcCatalog, one for point data (Spot height) and the other for linear data (Contour line).

- The boundary map is overlayed on the extracted toposheet.

- The editing tool was used to digitize the spot height and the contour lines and the values recorded in the attribute table accordingly.

- The symbols are then adjusted accurately.

\subsection{Generation of a Land Use/Land Cover Map of Surulere}

- The 1 m resolution Ikonos imagery (with bands 1, 2, 3 and 4 already layer stacked), which was already 


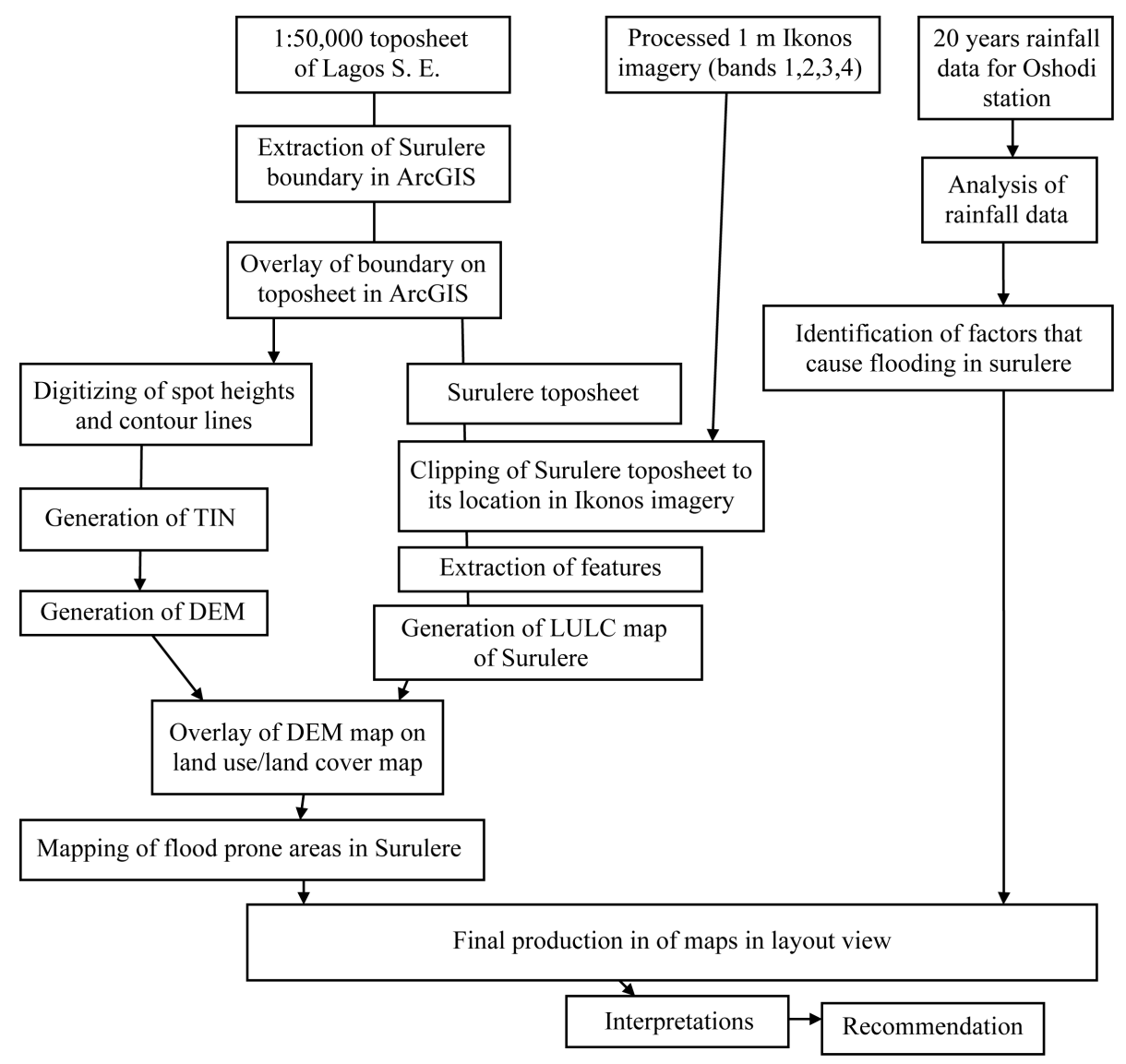

Figure 4. Methodological flow chart of the research design.

processed was imported into the GIS environment.

- The extracted Surulere topomap was clipped to its location on the satellite imagery by going to the ArcToolbox $\rightarrow$ data management tools $\rightarrow$ Raster processing $\rightarrow$ clip.

- Layers of Prominent features were then extracted the clipped imagery by vectorization. The features extracted include water bodies, built-up areas, different classes of vegetation, Scattered/open areas.

\subsection{Generation of a Digital Elevation Model of Surulere}

In creating a DEM of the area, using the contour lines generated, the following steps were taken. (Note the DEM was created using the Triangular Irregular Network (TIN)).

- First, the arc toolbox was launched.

- The 3D analyst extension was activated by clicking on Customize $\rightarrow$ Extensions $\rightarrow$ 3D analyst tools.

- The TIN tool was then opened by clicking on ArcToolbox $\rightarrow$ 3D Analyst tools $\rightarrow$ TIN Management $\rightarrow$ Create TIN.

- After clicking on the Create TIN icon, the contour layer was then inputed and the DEM generated: Create TIN $\rightarrow$ Output TIN $\rightarrow$ Select output folder $\rightarrow$ Input spatial reference $\rightarrow$ Input feature class (the contour layer) $\rightarrow$ add the height field $\rightarrow$ ok. (The DEM is generated).

- The colour ramp of the generated DEM is then changed by right clicking on the DEM layer $\rightarrow$ click on properties $\rightarrow$ elevation $\rightarrow$ change the colour ramp.

- The classification method was then edited by clicking on classification (still under properties) $\rightarrow$ classification method $\rightarrow$ equal interval $\rightarrow$ No of classes (the number of classes was changed to 9) $\rightarrow$ Apply $\rightarrow$ Ok.

- The DEM was then converted to raster using conversion tools by going to 3D analyst tools $\rightarrow$ conversion $\rightarrow$ From Tin $\rightarrow$ Tin to raster $\rightarrow$ Input Tin. 


\subsection{Mapping of Flood Prone Areas in Surulere}

- The generated DEM map was overlayed on the Land use/Land cover map.

- All areas below 60ft were mapped as areas more prone to flooding, while areas btw 60 and $100 \mathrm{ft}$ were mapped out as areas more prone to flooding.

- Also, built up areas close to water bodies were also considered as areas prone to flooding.

\subsection{Production of Generated Maps}

All the generated maps were taken one by one to the layout view, by clicking on the layout view icon

- The graticule was inserted by clicking on view $\rightarrow$ dataframe properties $\rightarrow$ grid $\rightarrow$ graticule.

- The other map features such as the neatline, legend, scale text, scale bar, north arrow and title were all included in the various maps by clicking on insert and selecting the features.

- After the maps features were properly placed and positioned, the maps were exported by clicking on file $\rightarrow$ export map. All maps were saved in pdf format and printed.

\section{Results and Discussion}

\subsection{Factors That Contribute to Flooding in Surulere}

The rainfall data analysis carried out shows that over the years, the rainfall amount in the study area has significantly high. There has been some consistency in the rainfall pattern with slight variations. The mean monthly rainfall is $120.2 \mathrm{~cm}$ while the mean annual rainfall is $1441.22 \mathrm{~cm}$. (See Table 2).

Table 2 shows that the rainfall amounts over the period covered is relatively high. In the Figure 5 below, it can be seen that over the years, Surulere has experienced a steady rise in annual rainfall, although there was a decrease between year 1995 and 2000. However, there has been a steady increase ever since and the trend is most likely to continue due to global warming.

The Field Survey carried out shows that a lot of houses in Surulere are constructed on drainage channels. Also, some roads are constructed without adequate drainage channels for water flow. Some of the drainage channels available are blocked due to continuous dumping of refuse in the channels e.g. in Cele and Itire areas.

Figure 6 displays the topography of the study area. The relief and DEM maps generated show that Surulere is a relatively flat land, with the highest elevated peak at 100ft (See Figure 7 and Figure 8). Majority of the land area is below $50 \mathrm{ft}(15 \mathrm{~m})$; some areas are even as low as $30 \mathrm{ft}$. Therefore, it can be classified as a lowland, thus making it difficult for accumulated water from rainfall to flow to the lagoons and creeks.

The land use/land cover map generated (Figure 9 and Figure 10) shows that majority of the study area is

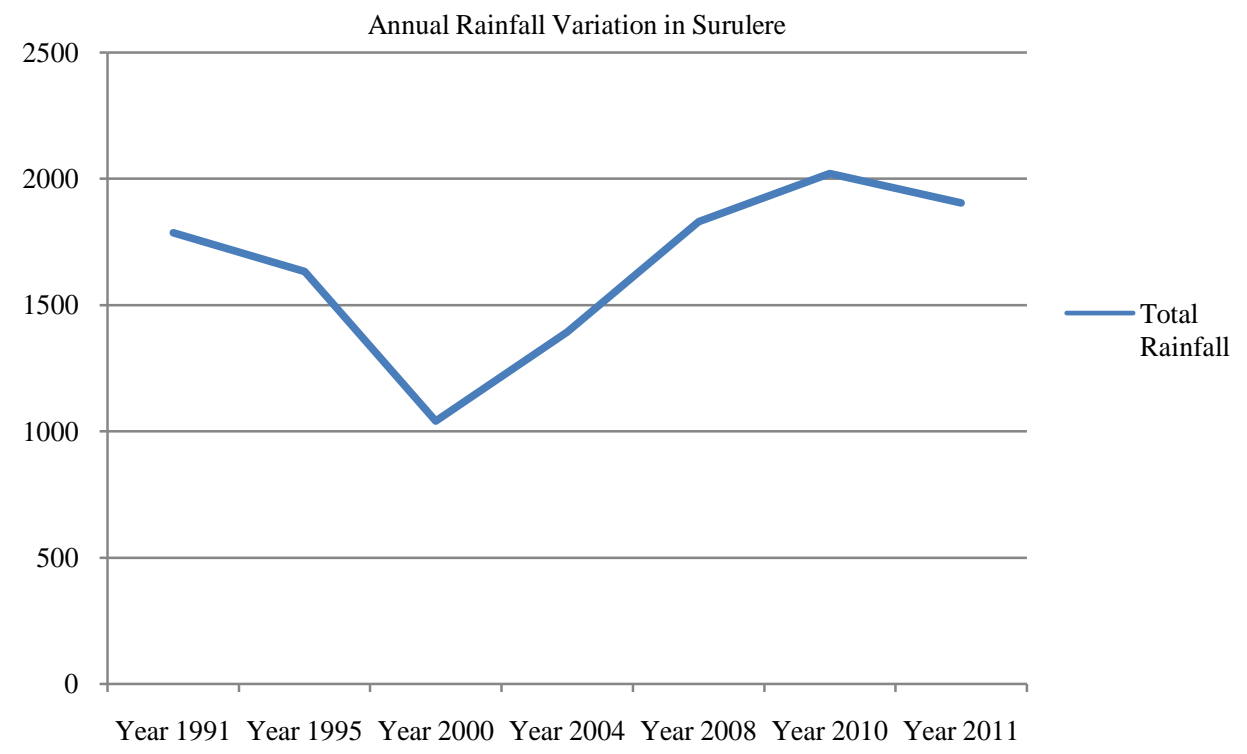

Figure 5. Annual variation in rainfall totals in the study area. 
Table 2. 20 years monthly rainfall data (in $\mathrm{cm}$ ) for Oshodi met station (Source of data: NIMET, Oshodi).

\begin{tabular}{|c|c|c|c|c|c|c|c|c|c|c|}
\hline OSHODI & 1991 & 1992 & 1993 & 1994 & 1995 & 1996 & 1997 & 1998 & 2000 & 2001 \\
\hline JAN & TR & 0 & TR & 51.6 & TR & 8.5 & TR & TR & TR & 7.5 \\
\hline FEB & 13.6 & TR & 53.8 & 8.3 & 73.4 & 108.6 & 0 & 33.3 & 33.3 & 4.4 \\
\hline MAR & 69.7 & 44.7 & 111.3 & 56.3 & 165.3 & 94.6 & 126.5 & 20.3 & 20.3 & 12.9 \\
\hline APR & 288.3 & 84.1 & 187.5 & 591 & 168.7 & 241.5 & & 54.8 & 54.8 & 212.5 \\
\hline MAY & 224.7 & 426.4 & 252.7 & 145.1 & 236 & 176.7 & 223.8 & 114.7 & 114.7 & 206.9 \\
\hline JUN & 424.8 & 278.6 & 273 & 330.9 & 287.2 & 223.1 & 427.4 & 204.9 & 204.9 & 214.6 \\
\hline JUL & 357.1 & 144.6 & 118.9 & 80.8 & 280.4 & 301.9 & 70.5 & 87.3 & 87.3 & 101.5 \\
\hline AUG & 41.5 & 16.4 & 28.1 & 28.6 & 98.9 & 170.5 & 120.1 & 93.6 & 93.6 & 24.1 \\
\hline SEPT & 215.7 & 162.4 & 163.5 & 139.4 & 108.5 & 125.3 & 123.3 & 291.8 & 291.8 & 199.4 \\
\hline OCT & 143.3 & 100.3 & 110.8 & 154.7 & 151.2 & nil & & 83.8 & 83.8 & 108.5 \\
\hline NOV & 7.7 & 69.2 & 94.9 & 6.4 & 21.9 & & 56.8 & 38 & 38 & 12 \\
\hline DEC & 0 & 21.4 & 9.8 & 10.2 & 40.9 & & & 17.8 & 17.8 & 13.3 \\
\hline ANNUAL & 1786.4 & 1348.1 & 1404.3 & 1603.3 & 1632.4 & 1450.7 & 1148.4 & 1040.3 & 1040.3 & 1117.6 \\
\hline MONTHLY & 148.87 & 112.34 & 117.03 & 133.61 & 136.03 & 120.89 & 95.70 & 86.69 & 86.69 & 93.13 \\
\hline MAX & 357.1 & 426.4 & 252.7 & 330.9 & 287.2 & 301.9 & 427.4 & & 291.8 & 214.6 \\
\hline MAX MNT & JUL & MAY & MAY & JUN & JUN & JUL & JUN & & SEPT & JUN \\
\hline MIN & 0 & 0 & $\mathrm{TR}$ & 6.4 & TR & 8.5 & 0 & & $\mathrm{TR}$ & 7.5 \\
\hline MIN MNT & DEC & JAN & JAN & NOV & JAN & JAN & FEB & & JAN & JAN \\
\hline OSHODI & 2002 & 2003 & 2004 & 2005 & 2006 & 2007 & 2008 & 2009 & 2010 & 2011 \\
\hline JAN & TR & 63.2 & 10.4 & 0 & 81.7 & 0 & 1.8 & 1.3 & 49.3 & 0 \\
\hline FEB & 34.4 & 35.3 & 75 & 73.1 & 15.2 & 1.1 & 24.2 & 17.6 & 48.8 & 184.4 \\
\hline MAR & 28.4 & 75.2 & 113.9 & 56.7 & 93.6 & 62.8 & 85.2 & 66.8 & 70.1 & 5.1 \\
\hline APR & 215.1 & 491.7 & 143.9 & 80.6 & 15.3 & 19.2 & 57.5 & 178.6 & 139.1 & 64.4 \\
\hline MAY & 129.4 & 136.2 & 266.1 & 226.2 & 234.8 & 129.2 & 178.1 & 154.1 & 124.3 & 226.8 \\
\hline JUN & 206.7 & 241.5 & 204.8 & 250.7 & 177.6 & 403.3 & 349.6 & 462.2 & 424.5 & 332.3 \\
\hline JUL & 403.3 & 51.4 & 47.7 & 280.7 & 186.1 & 235.2 & 412.8 & 162.8 & 112.9 & 424.2 \\
\hline AUG & 43.9 & 16.6 & 22.5 & 3.6 & 46 & 212.4 & 169.7 & 34.3 & 276.9 & 56.9 \\
\hline SEPT & 141.7 & 99.3 & 286.4 & 137.7 & 314.6 & 107 & 255.5 & 88.9 & 229.5 & 208 \\
\hline OCT & 152.4 & 77.8 & 192.8 & 77.6 & 83.2 & 100.9 & 79.8 & 200.1 & 351.9 & 256.9 \\
\hline NOV & 46.5 & 130.8 & 30.1 & 43.5 & 23.3 & 27.6 & 155.3 & 43.2 & 138.6 & 145.2 \\
\hline DEC & 25.8 & $\mathrm{TR}$ & 0 & 21.3 & 0 & 23.3 & 60.6 & 1.8 & 55.3 & 0 \\
\hline ANNUAL & 1427.6 & 1419 & 1393.6 & 1251.7 & 1271.4 & 1322 & 1830.1 & 1411.7 & 2021.2 & 1904.2 \\
\hline MONTHLY & 118.97 & 118.25 & 116.13 & 104.31 & 105.95 & 110.17 & 152.51 & 117.64 & 168.43 & 158.68 \\
\hline MAX & 215.1 & 491.7 & 286.4 & 280.7 & 314.6 & 403.3 & 412.8 & 462.2 & 424.5 & 424.2 \\
\hline MAX MNT & APR & APR & SEPT & JUL & SEPT & JUN & JUL & JUN & JUN & JUL \\
\hline MIN & TR & TR & 0 & 0 & 0 & 0 & 1.8 & 1.3 & 48.8 & 0 \\
\hline MIN MNT & JAN & DEC & DEC & JAN & DEC & JAN & JAN & JAN & FEB & JAN/DEC \\
\hline \multicolumn{11}{|c|}{ Mean Monthly Rainfall = 120.01} \\
\hline & & Mea & Annual $\mathbf{R}$ & fall $=14$ & $22 \mathbf{T R}=$ & ace Amo & of Rain & & & \\
\hline
\end{tabular}




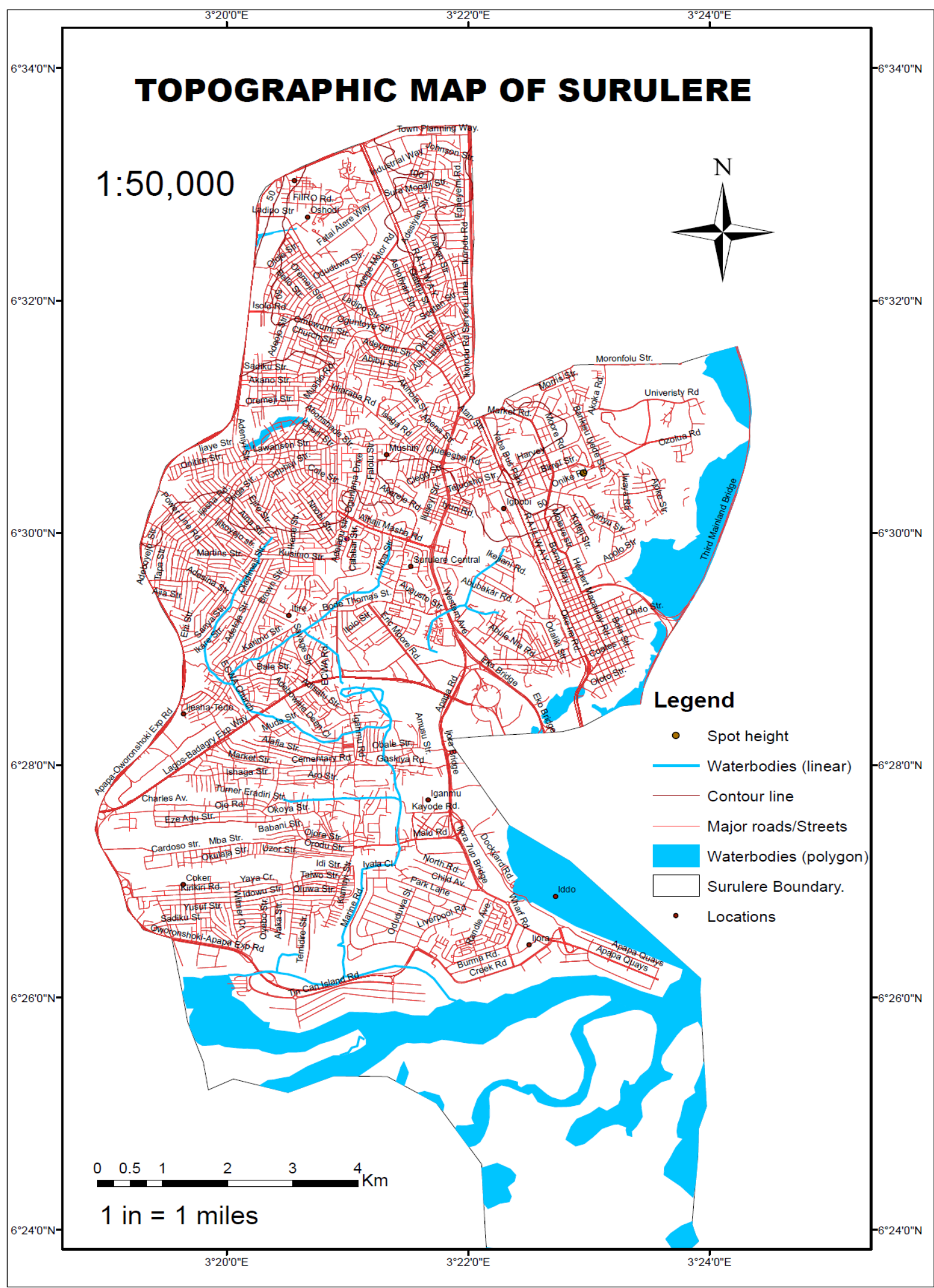

Figure 6. Topographic map of Surulere. 


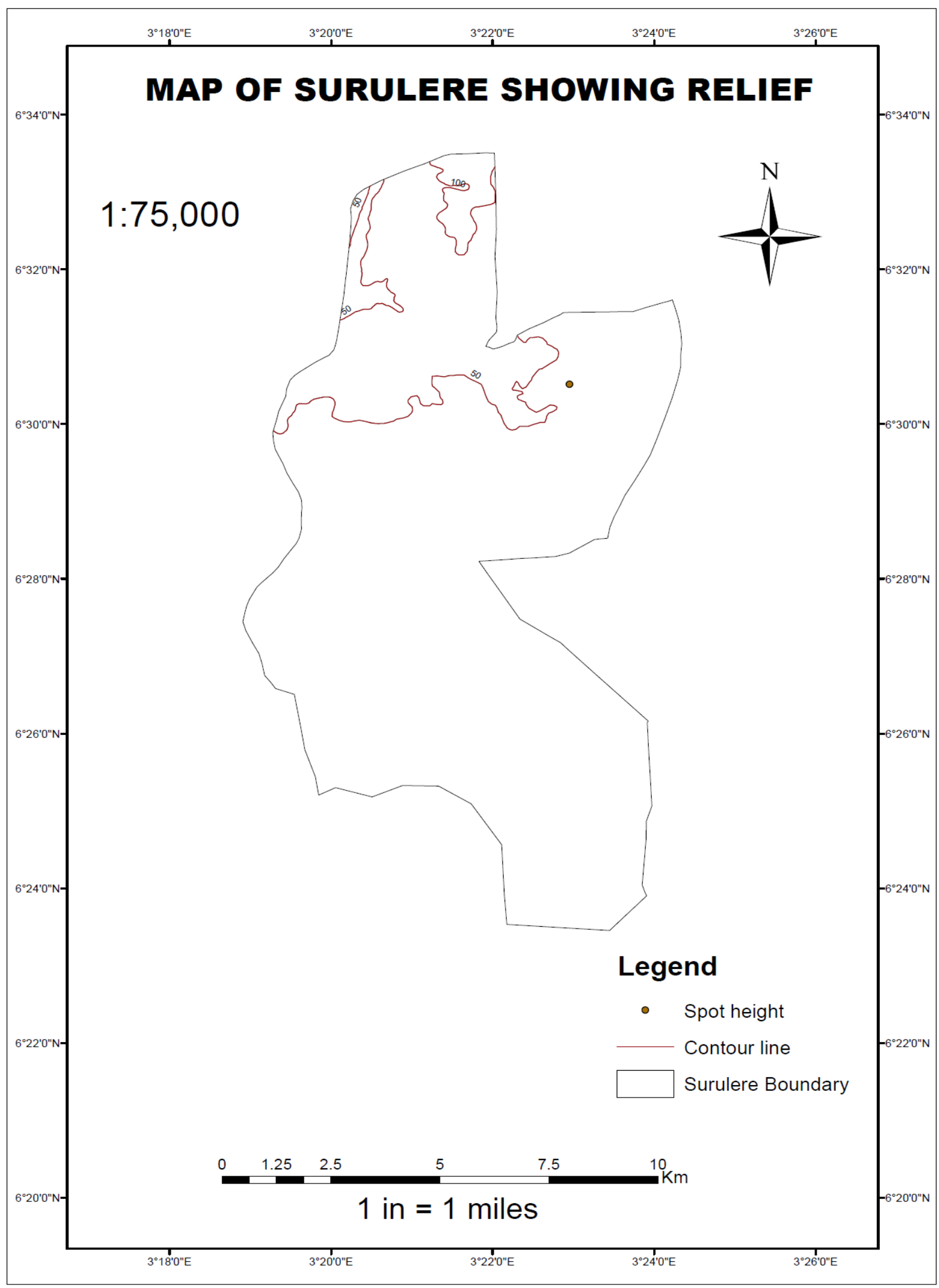

Figure 7. Map of Surulere showing relief. 


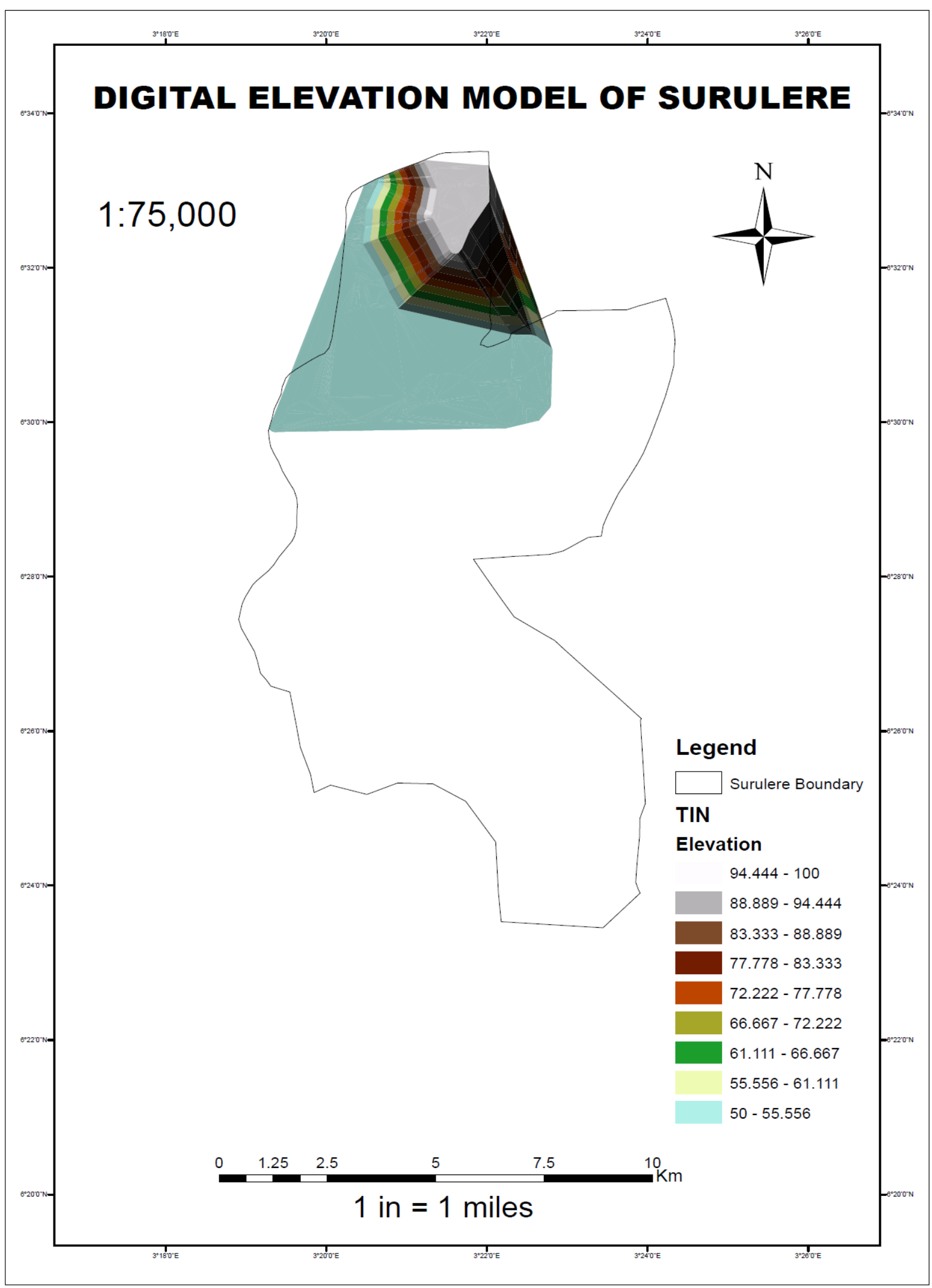

Figure 8. Map of Surulere showing DEM generated. 


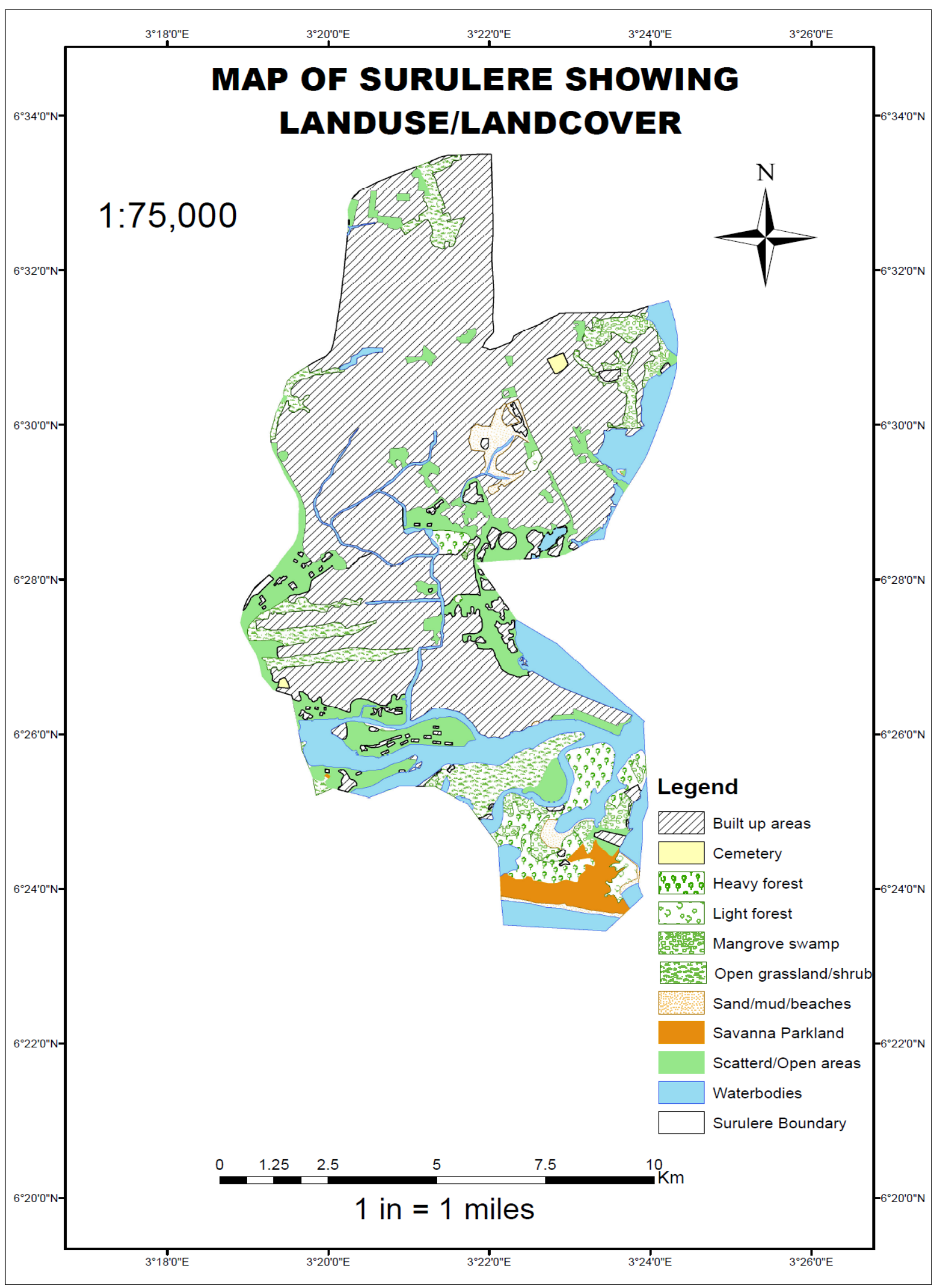

Figure 9. Map of study area showing land use/land cover classification. 
built up. The area doesn't have sufficient drainage channels. A lot of the buildings are either constructed along drainage channels or blocking drainage paths.

The pie chart above shows that a major percentage of the study area is built-up.

From the Table 3, it can be seen that $46.09 \%$ of the land area is built up while $24.54 \%$ are open/scattered areas. Therefore, most of the land surface is impermeable and rainwater falling cannot be absorbed into the underground soil. There is also a presence of swampy vegetation and water bodies. Most of the features in the built up areas i.e. roads, buildings, etc. are constructed along drainage channels, preventing free flow of water thereby causing rainwater to accumulate on the land surface, causing flooding.

Therefore, in summary, the factors that contribute to flooding in Surulere are:

- High rainfall amounts, intensity and duration.

- Majority of the area is built up, with little or no permeable layer.

- Construction of buildings along drainage channels.

- Construction of roads without adequate drainage channels.

- Refuse being dumped in drainage channels.

- Construction of buildings close to water bodies.

- The lowland topography of Surulere.

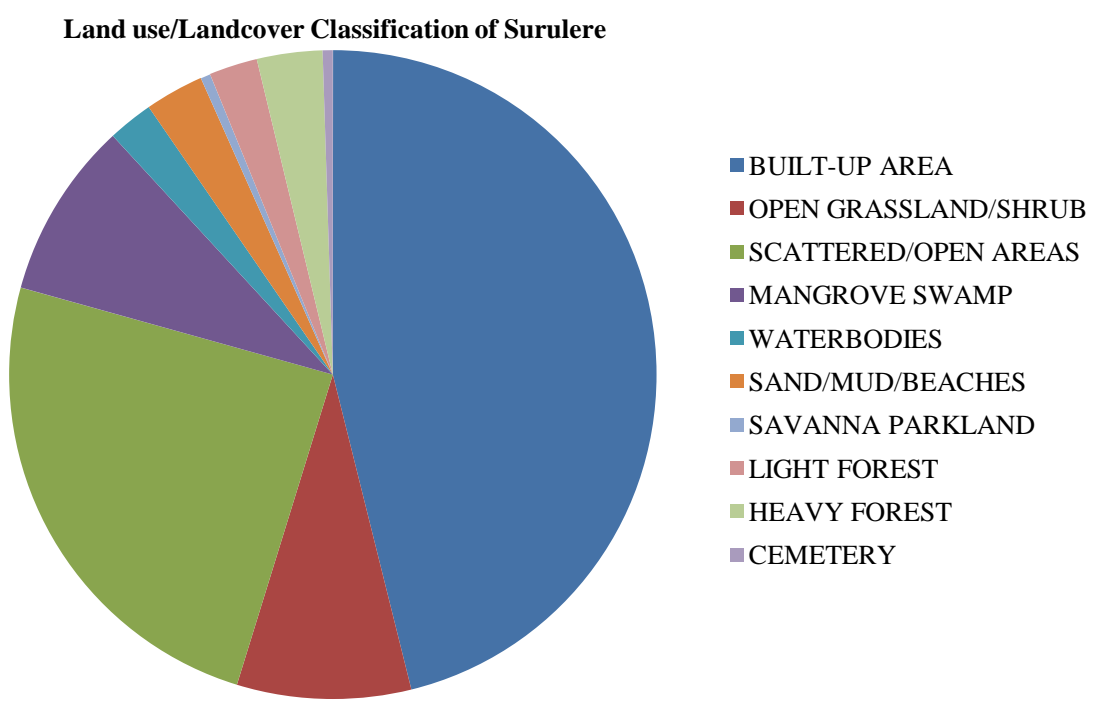

Figure 10. Pie chart showing LULC classification.

Table 3. Land use/land cover classification of Surulere.

\begin{tabular}{cccc}
\hline LULC Class & Area $(\mathrm{sq} \cdot \mathrm{m})$ & Perimeter & \% Coverage \\
\hline Built-up Area & 30455.46 & 37905.67 & 46.09 \\
Open Grassland/Shrub & 5741.4 & 5398.1 & 8.69 \\
Scattered/Open Areas & 16218.4 & 15841.08 & 24.54 \\
Mangrove Swamp & 5818.81 & 2730.4 & 8.81 \\
Waterbodies & 1490.09 & 2565.61 & 2.26 \\
Sand/Mud/Beaches & 1940.45 & 4018.32 & 2.94 \\
Savanna Parkland & 322.93 & 749.56 & 0.49 \\
Light Forest & 1592.27 & 1750.53 & 2.41 \\
Heavy Forest & 2166.16 & 2918.94 & 3.28 \\
Cemetery & 332.84 & 1312.42 & 0.50 \\
Total & 66078.81 & 75190.63 & 100
\end{tabular}




\subsection{Identification of Flood Prone Areas in Surulere}

From the analysis carried out, the entire Surulere area can be said to be susceptible to flood due to combined factors mentioned above (See Figure 11). If adequate measures are not taken, with the high rainfall amounts and intensity experienced, the area is in danger of being overtaken by flood.

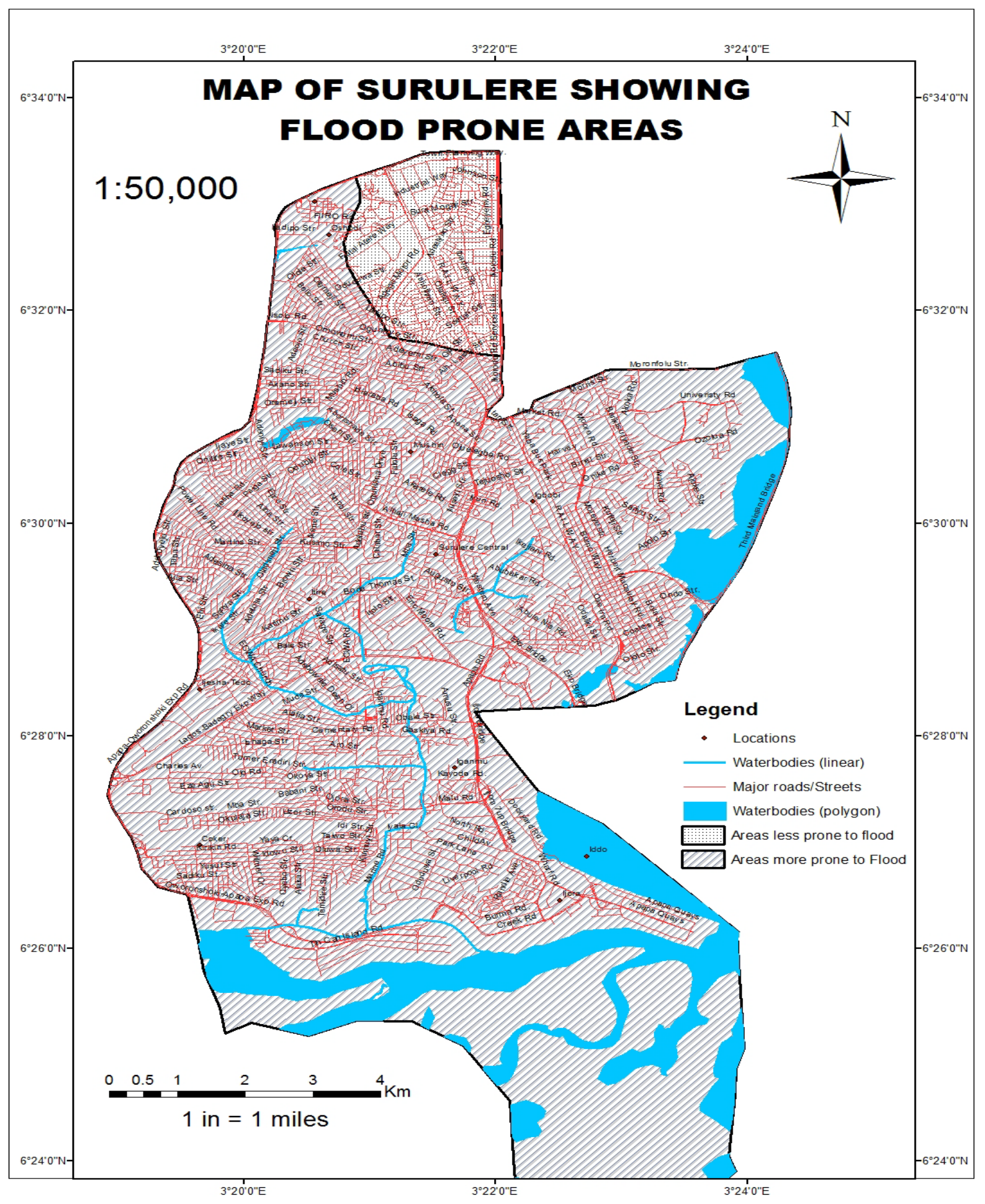

Figure 11. Map of study area showing flood prone areas. 


\section{Conclusion and Recommendations}

The purpose of this research work is to map the areas prone to flooding in Surulere. From the results of the analysis carried out, it is clear that the entire Surulere area is prone to flooding. This is due to a number of factors mentioned in the paper. If serious measures are not taken soon, taking the increasingly high rainfall into consideration, the area is in danger of being submerged with floods with lives and properties in danger of being destroyed. The year, 2014 alone, high rainfall intensity has led to flood incidents that left washed out roads, destroyed structures and loss of lives in its trail e.g. in the Ebute-metta, Cele and Aguda areas. Therefore, it is important for the Lagos State government to put in place measures to mitigate flooding in Surulere. Such measures include:

- Careful planning of development in potentially flood prone areas. This should be supported by appropriate legislation, public information and education programmes (to ensure that residents understand the flood risk), flood insurance, and flood warning systems (to reduce the impact of floods).

- Flood forecasting and flood warning services. This service has been readily provided by the Nigerian Meteorological Agency.

- Roads should be constructed with proper drainage channels and dumping of refuse in drainage channels should be prohibited and penalties attached to non-adherence.

- More drainage channels and reservoirs should be constructed such as canals and gutters. Side drains and gutters could have removable precast concrete or steel cover for ease of maintenance. Water meadow areas can be created with which to divert flood water.

- Drainage channels should be cleaned out regularly to avoid blockage by silts and mud. This can be achieved by enforcing the monthly environmental sanitation by the local government authorities.

- Runoff control - source control measures should be put in place to reduce the amount of runoff in the event of flooding. These measures include construction of permeable pavements, afforestation and artificial recharge. Also stores of runoff can be created such as wetlands, detention basins and reservoirs [18].

- More in-depth research should be carried out on the impact of global climate change and associated impacts on floods.

- Flood risk maps should be produced and a comprehensive floodplain management plan should be developed for areas likely to be affected by floods. Also flood management studies should be carried out to discover more advanced and effective ways to control flooding.

- The government should put a ban on the construction of buildings on flood plains with penalties attached. However, there should be adequate awareness and dissemination of this information in the media and also the availability of flood risk maps to the public.

- Residents of Surulere, as groups and as individuals, and corporate bodies should be implored and encouraged to embark on some palliative measures such as dredging and re-dredging of drains, erosion passages and others; and construction of embankments and channelization of some routes that are prone to flooding.

- Resettlement strategies and emergency preparedness plans should be developed by the involved the government in order to easily evacuate citizens in the occurrence of flood disasters.

Reference [18] best summarized the need for emergency plans, stating as follows:

"Flood warnings and timely emergency action are complimentary to all forms of intervention. A combination of clear and accurate warning messages with a high level of community awareness gives the best level of preparedness for self-reliant action during floods. Public education programs are crucial to the success of warnings intended to preclude a hazard from turning into a disaster. Evacuation is an essential constituent of emergency planning and evacuation routes may be upward into a flood refuge at a higher elevation or outward, depending upon the local circumstances. Outward evacuations are generally necessary where the depths of water are significant, where flood velocities are high and where the buildings are vulnerable. Successful evacuations require planning and awareness among the population of what to do in a flood emergency. Active community participation in the planning stage and regular exercises help ensure that evacuations are effective. The provision of basic amenities such as water supply, sanitation and security in areas where refugees gather is particularly important in establishing a viable evacuation system."

- Finally, Flood recovery measures such as counseling, compensation and insurance should be put in place. The pros and the cons of the policy of flood insurance should however be weighed before implemented. Also, the sociological aspects of coping with flood in affected areas should be taken seriously and appropriate 
counseling given to affected victims.

Currently, Some of these measure are already being put in place by the Lagos State government. An article in the [19] stated, "Given the prediction of Nigerian Meteorological Agency (NIMET) that this year will witness heavy rains, the Lagos Government has commenced construction of drainages and canals in the Surulere Local Government Area to reduce the impacts on its citizens”.

Also, The Lagos State Government is clearing slums, especially those on the drainage channels and right of way. Recently, at Adelabu area in Surulere, behind an elitist school, Fountain Heights Secondary School, a slum community of over 2,000 inhabitants including women and children, were given an eviction notice to allow for the construction of channels and drainage to check flooding in Surulere, which has been a yearly occurrence due to the activities of these people [19]. Also, the Lagos state commissioner for environment, Mr Tunji Bello said that the government would no longer tolerate the construction of shanties and on drainage channels.

However, the governments both at the state and local levels have to do more in order to prevent/reduce future occurrences of flooding in Surulere. If all or most of the measures listed above are taken into consideration and embarked on, flood incidences in Surulere would be greatly reduced.

\section{References}

[1] Ojeh, V.N. and Ugboma, P. (2012) Flood Hazards in Urban Niger Delta: A Case Study of Abraka Town, Delta State, Nigeria. International Journal of Environmental Engineering Research, 1, $23-29$.

[2] Ojeh, V.N. and Victor-Orivoh, A.F. (2014) Natural Hazard and Crop Yield in Oleh, South-South Nigeria: Flooding in Perspective. Journal of Earth Science \& Climatic Change, 5, 181. http://dx.doi.org/10.4172/2157-7617.1000181

[3] Etuenovbe, A. (2011) The Devastating Effect of Flooding in Nigeria. http://www.fig.net/pub/fig2011/papers/ts06j/ts06j etuonovbe 5002.pdf

[4] Water Words Dictionary (2000) A Compilation of Technical Water, Water Quality, Environmental, and Water-Related Terms. Nevada Division of Water Planning Department of Conservation and Natural Resources, 495.

[5] Nkeki, F.N., Henah, P.J. and Ojeh, V.N. (2013) Geospatial Techniques for the Assessment and Analysis of Flood Risk along the Niger-Benue Basin in Nigeria. Journal of Geographic Information System, 5, 123-135 http://dx.doi.org/10.4236/jgis.2013.52013

[6] Okonkwo, I. (2013) Effective Flood Plain Management in Nigeria: Issues, Benefits and Challenges. Transparency for Nigeria, 2013. http://transparencyng.com

[7] Aina, T.A., Etta, F.E. and Obi, C.I. (1994) The Search for Sustainable Urban Development in Metropolitan Lagos, Nigeria: Prospects and Problems. Third World Planning Review, 16, 201-219.

[8] Ogala, E. (2012) Four People Missing, Hundreds of Farmlands Submerged in Kogi Flood. Premium Times, September 28, 2012. http://www.premiumtimesng.com

[9] Vanguard Newspaper (2012) More Photos of Lagos Flood, by Citizen Reporters. Vanguard Newspaper, June 11, 2012. http://www.vanguardngr.com

[10] Uluocha, N.O. (2007) Elements of Geographic Information Systems. Sam Iroanusi Publications, Lagos.

[11] Longley, P.A., Goodchild, M.F., Maguire, D.J. and Rhind, D.W. (2005) Geographical Information Systems: Principles, Techniques, Management and Applications. John Wiley and Sons Ltd., New Jersey.

[12] Sutton, T., Dassau, O. and Sutton, M. (2009) A Gentle Introduction to GIS. Chief Directorate: Spatial Planning \& Information, Department of Land Affairs, Western Cape.

[13] Olajuyigbe, A.E., Rotowa, O.O. and Durojaye, E. (2012) An Assessment of Flood Hazard in Nigeria: The Case of Mile 12, Lagos. Mediterranean Journal of Social Sciences, Department of Urban and Regional Planning, Federal University of Technology, Akure, 3, 367-375.

[14] Oyinloye, M., Olamiju, I. and Ogundiran, A. (2013) Environmental Impact of Flooding on Kosofe Local Government Area of Lagos State, Nigeria: A GIS Perspective. Journal of Environment and Earth Science, Department of Urban and Regional Planning, School of Environmental Technology, Federal University of Technology, Akure, 3.

[15] Associated Programme on Flood Management [APFM] (2013) Urban Floods: What Are the Negative Social Impacts of Flooding? http://www.apfm.info/?p=2459

[16] National Rainfed Area Authority (2011) The Impact of High Rainfall and Floods on Ground Water Resources in the Krishna River Basin (during 1999-2009). National Rainfed Area Authority, Planning Commission, New Delhi.

[17] Lagos Bureau of Statistics (2012) Abstract of Local Government Statistics. Lagos Bureau of Statistics, Ministry of Economic Planning and Budget, Ikeja, Lagos. 
[18] WMO (2009) Integrated Flood Management Concept Paper. Associated Programme on Flood Management, World Meteorological Organization, WMO-No. 1047, 2009.

[19] The Guardian Newspaper (2013) Lagos Engages Constructors in Surulere Drainage Project. The Guardian Newspaper, Monday, March 3rd, 2013. 